\title{
Article \\ Optimal Techno-Economic Planning of a Smart Parking Lot-Combined Heat, Hydrogen, and Power (SPL-CHHP)-Based Microgrid in the Active Distribution Network
}

\author{
Hamed Hosseinnia ${ }^{1}$, Behnam Mohammadi-Ivatloo ${ }^{2, *(D)}$ and Mousa Mohammadpourfard ${ }^{3}$ \\ 1 Faculty of Electrical and Computer Engineering, University of Tabriz, Tabriz 5166616471, Iran; \\ Hamed.Hosseinnia@gmail.com \\ 2 Smart Energy Systems Lab., Faculty of Electrical and Computer Engineering, University of Tabriz, \\ Tabriz 5166616471, Iran \\ 3 Faculty of Chemical and Petroleum Engineering, University of Tabriz, Tabriz 5166616471, Iran; \\ mohammadpour@tabrizu.ac.ir \\ * Correspondence: bmohammadi@tabrizu.ac.ir
}

Citation: Hosseinnia, H.;

Mohammadi-Ivatloo, B.;

Mohammadpourfard, M. Optimal

Techno-Economic Planning of a Smart

Parking Lot-Combined Heat,

Hydrogen, and Power

(SPL-CHHP)-Based Microgrid in the Active Distribution Network. Appl.

Sci. 2021, 11, 8043. https://doi.org/ 10.3390/app11178043

Academic Editor: Luis

Hernández-Callejo

Received: 8 August 2021

Accepted: 24 August 2021

Published: 30 August 2021

Publisher's Note: MDPI stays neutral with regard to jurisdictional claims in published maps and institutional affiliations.

Copyright: (c) 2021 by the authors. Licensee MDPI, Basel, Switzerland. This article is an open access article distributed under the terms and conditions of the Creative Commons Attribution (CC BY) license (https:// creativecommons.org/licenses/by/ $4.0 /)$
Abstract: By installing distributed generation (DG) sources in a distribution system, there is a change from the inactive state, accompanied by one-way power flow, to the active state, with the possibility of bilateral power flow. Authorities involved in the electricity industry manage the consumption side by bringing in particular programs called demand response programs. To implement these programs, it is crucial to create infrastructure, including the installation of smart measuring units in the consumption sector. In this paper, we investigate the optimal design of smart meters and combined hydrogen, heat, and power in the active distribution system to provide two functions aimed at reducing voltage drop and minimizing the total planning costs by taking different scenarios into account. In the combined hydrogen, heat, and power (CHHP)-based DGs, due to the low efficiency of the electrolyzer, its power is supplied by a smart parking lot (including wind turbines, photovoltaic systems, and batteries). To model the unit's uncertainties, a long short-time memory (LSTM) model is employed. Utilizing the technique for order preference by similarity to ideal solution (TOPSIS), a state that enhances both functions is acquired from different scenarios. All of the simulations are carried out in two 33-bus systems.

Keywords: combined hydrogen, heat, and power (CHHP); smart meter (SM); long short-time memory (LSTM) model; technique for order preference by similarity to ideal solution (TOPSIS)

\section{Introduction}

The distribution system is the last node of the traditional power system in direct contact with consumers and is accountable for fulfilling the current demands with high quality and minimum load curtailment. Given the security problems and the extortionate cost of power system operators in the construction of new power plants, as well as environmental and economic issues due to fossil fuel supplies for power plants, and the low efficiency of the conventional power system, those involved in the electricity industry have considered using alternative sources. The essential factors in selecting new sources are availability, cleanliness, and affordability of energy production. Solar power was suggested as an alternative source, but owing to the instability of this resource and energy supply only by day, there is a dire need to use energy storage. The combination of resources and storage is called distributed generation resources. Using these resources in the distribution system converts the one-way power flow to bilateral power flow. It also changes the distribution system from a pure consumer sector to an active and productive state. Therefore, the distribution system becomes an active distribution network. Proper installation and operation of these resources necessitate developing a telecommunications platform and obtaining constant information on production and consumption rates. Such a network is called a 
smart network. To correctly manage the consumption side, programs are defined as load response programs to reduce the issues related to the network's peak load and ensure a uniform load curve by modifying the consumption pattern. Network smartening should also be performed in the transportation sector to decrease the environmental problems caused by internal combustion vehicles. Given the spectacular advances in materials science and batteries, electric vehicles have been proposed as an alternative. It is necessary to construct car stations to provide battery power for these cars in particular places. With the introduction of the V2G concept, cars are able to inject power into the network, and officials began to contemplate managing them for use as virtual power plants. Station owners have installed other distributed generation sources and storage facilities to make high profits. These stations are known as smart stations. Subsequently, the studies conducted on the installation of distributed generation sources and their construction in the distribution system are reviewed herein. Cogenerations are another type of DG that meet several kinds of energy demands. Combined heat and power (CHP) is the traditional cogeneration unit. Combined hydrogen, heat, and power (CHHP) meets heat, hydrogen, and power demands simultaneously. CHHP includes an electrolyzer, fuel cell, heat exchange unit, and thermal and hydrogen storage units. Due to the low efficiency of the electrolyzer, its input power is fed by a smart parking lot (SPL).

Determining the optimal size of distributed generation resources is done in local modes and the grid-connected mode. In [1], the optimal design of an energy hub with various energy systems was investigated. Simultaneous generation of electricity and heat and natural gas boilers was considered in the energy hub. In research carried out in Darmustach, Massachusetts, to reduce energy costs and environmental concerns, economic parameters were considered as uncertainties, and the results confirmed the feasibility of the plan [2]. The feasibility of installing micro-turbines in United Kingdom buildings was evaluated [3]. Utilizing electrical storage devices for microgrid management was analyzed using a new optimization algorithm called the bat algorithm [4]. The results demonstrate the positive effect of adding storage facilities to reduce system operating costs and boost the quality of energy supply to consumers.

In [5], the impact of private sector investors' participation and the distribution system operator on the profits of the involved parties was studied. The private sector investor owns a photovoltaic system and electric energy storage. In addition to providing the profit function, the distribution system's technical constraints were also improved compared to the base state. Various plans have been taken into consideration by power system officials to make the energy sector more attractive to private sector investors. In [6], the profit function of the distribution system operator was integrated with the private sector investor's profit function to attain satisfactory answers for both parties in different cases by solving these functions.

In general, there are three types of loads: industrial, commercial, and household. Household load requires the appropriate selection of the type of distributed generation source due to the electrical and thermal demand. In [7], the authors utilized the simultaneous generation of heat and electricity and diesel generators to supply the energy required by household consumers. Moreover, they applied thermal and electrical storage for proper management of the two types of demand, electrical and thermal. Consumption-side management includes the establishment of programs called demand response programs to improve the daily load curve to prevent coups and sudden power outages for consumers. In [8], the issue of optimal microgrid design was investigated by considering an objective function based on reliability. The effect of the load response program on the network load curve and the overall cost was also examined. To increase the effect of the DR program in short-time studies, additional investment was applied [9]. Real-time response capability was provided by integrating DR control and air conditioners into the basic electronic devices [10]. Different methods have been introduced to model system uncertainties. Monte Carlo (MC), the point estimate method, the symmetric two-point estimate method (S2PEM), fuzzy logic, and artificial intelligence algorithms are common approaches to modeling un- 
certainties. In [11], a combination of the MC method and linearized power flow equations was employed to model probabilistic planning problems. In order to make much fewer simulations, the authors employed S2PEM and utilized deterministic routines to find the statistical moments of the time series [12]. The fuzzy logic model was employed to model load and power flow equations' probabilistic behavior [13], and an intelligent network was used to model the market pricing model [14]. ISO made a decision to choose the best bids among all of the DISCOS proposed prices. All of the bids were offered by considering the predicted load curve and energy demand [15]. In [16], the authors proposed electrolyzerand fuel-cell-based MG to meet both hydrogen and power energy demands. Due to the low efficiency of the electrolyzer, its input power is fed by a photovoltaic system [17]. Fuel-cell-based electric vehicles (FCBEVs) are also used as transportation vehicles [18]. There are several kinds of optimization algorithms to solve short-term and long-term issues. To solve the optimization scheduling problem, the authors proposed an ant colony algorithm [19]. In [20], the authors applied a combination of Tabu search (TS) and the particle swarm optimization (PSO) algorithm to solve a planning problem. In [21], the authors used general algebraic modeling system (GAMS) software to model the stochastic problem and, by implementing a mixed-integer linear program, achieved all of the optimal solutions. In [22], the authors presented a comprehensive study evaluating the impacts of battery storage in reducing the operational costs of MG. The positive effects of considering demand response and storage systems in the optimal management of a smart home were evaluated in [23]. In [24], the authors presented an effective strategy to reduce power and energy losses by using storage systems in the distribution network.

As can be seen from the latest literature, comprehensive studies that include effective predictive techniques to model system uncertainties and utilize simultaneous generation of power, hydrogen, and thermal energy are lacking in previous works.

In this study, the main objective is to optimally design an SPL-CHHP-based MG in the distribution system. The proposed station is equipped with a wind turbine, photovoltaic system, and a battery. The novelties of this research are classified as follows:

- Optimal planning of CHHP in the active distribution network;

- Employing the LSTM model to model wind and sun irradiation;

- Obtaining the CHHP's converged power by the LSTM;

- Employing TOPSIS as a multicriteria decision analysis method.

The rest of the paper is organized as follows. In Section 2, the problem definition is addressed. The genetic algorithm (GA) as an optimization algorithm is explained in Section 3. In Section 4, all of the obtained results are analyzed in detail. Section 5 concludes the paper.

\section{Problem Definition}

In this paper, the main objective is to simultaneously locate CHHP and SMs in active distribution networks to reduce losses and minimize the total planning cost at the same time. Two objective functions were defined to reduce losses and costs, as shown in Equations (1)-(4).

$$
\begin{gathered}
\text { OF } 1=V D I=(x, u)=\sum\left(\left|V_{i}\right|-1\right)^{2} \\
O F_{2}=\left(I C^{C H H P}+I C^{S P L}+\sum_{t=1}^{24}\left(\Phi_{1, t}+\Phi_{2, t}\right)\right) \\
\Phi_{1}=\sum_{t=1}^{T}\left(\left(\rho_{t} \times P_{t}^{U G}\right)+\left(C_{t}^{S P L} \times P_{t}^{S P L}\right)+\left(C_{t}^{C H H P} \times P_{t}^{C H H P}\right)\right) \\
\Phi_{2}=\sum_{t=1}^{T}\left(\left(D_{t}^{C H H P} \times P_{t}^{C H H P}\right)+\left(D_{t}^{S L P} \times P_{t}^{S L P}\right)+\left(D_{t}^{U G} \times P_{t}^{U G}\right)\right)
\end{gathered}
$$




\subsection{Load Uncertainty}

According to the possible behavior of distribution system subscribers in electricity consumption, daily load changes in each year of the planning course are modeled using three parameters. The first parameter is the load consumption rate in the first year of the planning period. Each year of the planning course is divided into Ndlf demand levels, and the duration of each demand level is $\tau_{h}$. The second parameter of the load model is the Demand Level Factor (DLF), which is acquired using the Probability Density Function (PDF) as follows. $\lambda$ is a random variable generated using the normal distribution function with a mean value of 0 and a standard deviation of 1 for each demand level. $\mu$ and $\sigma$ are the predicted values of the load demand level and its standard deviation, respectively $[25,26]$.

The default load demand curve is according to Equations (5)-(9). The amount of electricity consumed at each level of demand is calculated as follows, considering the load growth rate for each year of the planning course:

$$
\begin{gathered}
P_{i, t, h}^{e}=P_{i, \text { base }} \times D L F_{i, t, h}^{e} \times(1+\alpha)^{t} \\
Q_{i, t, h}^{e}=Q_{i, \text { base }} \times D L F_{i, t, h}^{e} \times(1+\alpha)^{t} \\
S_{i, t, h}^{e}=P_{i, t, h}^{e}+j Q_{i, t, h}^{e} \\
S_{i, \text { base }}=P_{i, \text { base }}+j Q_{i, \text { base }} \\
\sigma_{i, t, h}^{D}=0.01 \times \mu_{i, t, h}^{D}
\end{gathered}
$$

\subsection{Electricity Price Uncertainty}

The price of electricity purchased from the primary grid is determined based on electricity consumption and the behavior of the electricity market operator. This amount changes at each demand level, each year of the planning period. Changes in this quantity are modeled by multiplying two parameters: the base price of electricity for each demand level and the price level index. PLF is a price level index that indicates the electricity market behavior and is calculated using the probability density function as follows:

$\lambda$ is a random variable generated using the normal distribution function with a mean value of 0 and a standard deviation of 1 for each demand level. $\mu$ and $\sigma$ are the predicted values of the price level index and its standard deviation, respectively [27].

The default price level curve is as presented in Figure 1 and Equations (10)-(12).

$$
\begin{gathered}
\rho_{t, h}=\rho \times P L F_{t, h}^{e} \\
P L F_{t, h}^{e}=\mu_{t, h}^{\rho}+\lambda_{t, h}^{\rho, e} \times \sigma_{t, h}^{\rho} \\
\sigma_{t, h}^{\rho}=0.1 \times \mu_{t, h}^{\rho}
\end{gathered}
$$

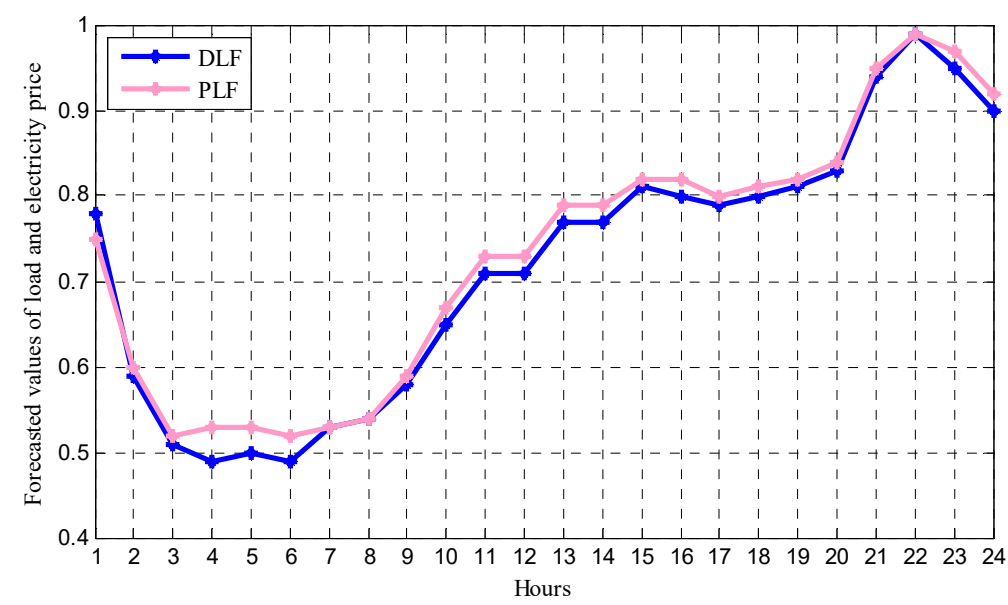

Figure 1. Price level curve. 


\subsection{Electric Vehicle Charging Station}

The charging station power depends on the car charging schedule and on factors such as the type and capacity of the car battery, the amount of initial charge of the battery, and the number of vehicles available at the station. The capacity and type of vehicle batteries attending the charging station are random parameters and depend on various factors such as the amount of each type developed and manufactured, the amount of public acceptance, and the area where the charging station is established. The access of each car at any hour depends on the times of arrival at and departure from the charging station, which is both accidental and caused by human behavior $[28,29]$.

$$
\begin{gathered}
S O C_{k}^{\text {initial }}=f\left(X ; \mu_{S O C} ; \delta_{S O C}^{2} ;\left(S O C_{k}^{\text {initial }, \text { min }} ; S O C_{k}^{\text {initial }, \text { max }}\right)\right. \\
t_{k}^{\text {arv }}=f\left(X ; \mu_{\text {arv }} ; \delta_{\text {arv }}^{2} ;\left(t_{k}^{\text {arv,min }} ; t_{k}^{\text {arv,max }}\right)\right. \\
t_{k}^{d e p}=f\left(X ; \mu_{\text {dep },} ; \delta_{\text {dep }}^{2} ;\left(t_{k}^{\text {dep,min }} ; t_{k}^{\text {dep,max }}\right)\right. \\
X_{t}^{E V, c h}+X_{t}^{E V, \text { disch }} \leq 1 \\
S O C_{E V}^{\min } \leq S O C_{t}^{E V} \leq S O C_{E V}^{\max } \\
0 \leq P_{t}^{E V, c h} \leq R_{E V}^{c h} \\
0 \leq P_{t}^{E V, \text { disch }} \leq R_{E V}^{\text {disch }} \\
S O C_{t}^{E V}=S O C_{t-1}^{E V}+\left(P_{t}^{E V, c h} \times \eta_{c h}^{E V}\right)-\left(P_{t}^{E V, \text { disch }} \times \eta_{\text {disch }}^{E V}\right) \\
S O C_{t}^{E V}=S O C_{E V}^{\text {initial }} i f t=t_{\text {arv }} \\
S O C_{t}^{E V}=S O C_{E V}^{\max } \text { ift }=t_{\text {dep }} \\
S O C_{t}^{E V}=P_{t}^{E V, c h}=P_{t}^{E V, \text { disch }}=0 \text { ift } t_{\text {dep }}<t<t_{\text {arv }}
\end{gathered}
$$

\subsection{Wind Turbine}

The power generation of a wind turbine depends on the wind speed factor in the study area. This parameter has no definite value and is random. Therefore, the location of this distributed generation unit will depend on how this parameter is modeled. In this regard, several experiments were conducted, which demonstrated that the Rayleigh Probability Density function is the preferable option for modeling the random behavior of wind speed. This function is a particular case of the Weibull Probability Density Function, in which the shape index is equal to $2 . v$ and $C$ are the wind speed and scale index in the Weibull distribution, respectively. After modeling the wind speed parameter, the power generated by the wind turbine is obtained according to Equation (27) [30].

$$
\begin{gathered}
f_{w g}(v)=\left(\frac{2 v}{c^{2}}\right) \exp \left(-\left(\frac{v}{c}\right)^{2}\right) \\
v_{m}=\int_{0}^{\infty} v f_{w g}(v) d_{v}=\int_{0}^{\infty}\left(\frac{2 v^{2}}{c^{2}}\right) \exp \left[-\left(\frac{v}{c}\right)^{2}\right] d_{v}=\frac{\sqrt{\pi}}{2} c \\
c \cong 1.128 v_{m} \\
P_{i, t, h}^{w g}=\left\{\begin{array}{cc}
0 & \text { if } v \leq v_{\text {in }}^{\text {cut }} \text { or } v \geq v_{\text {out }}^{\text {cut }} \\
P_{i, r}^{w,} \frac{v-v_{\text {in }}^{\text {cut }}}{v_{\text {rated }}-v_{\text {in }}^{\text {cut }}} & \text { if } v_{\text {in }}^{\text {cut }} \leq v \leq v_{\text {rated }} \\
P_{i, r}^{w} & \text { else }
\end{array}\right.
\end{gathered}
$$




\subsection{Photovoltaic System}

The photovoltaic system's output power depends on the amount of light received by the panels, the ambient temperature, the cross section of the panels, and its efficiency. The amount of light emitted by the sun has possible behavior expressed as follows [31].

$$
\begin{gathered}
f(I r)=\frac{\Gamma(\alpha+\beta)}{\Gamma(\alpha) \times \Gamma(\beta)} \times I r^{(\alpha-1)} \times(1-I r)^{(\beta-1)} \\
\beta=(1-\gamma)\left(\frac{(\gamma \times(1+\gamma)}{\delta^{2}}-1\right) \\
\alpha=\frac{\gamma \times \beta}{1-\gamma}
\end{gathered}
$$

The output power of the PV system can be calculated as follows:

$$
P_{i}^{P V}=S_{i} \times \eta \times I r
$$

\subsection{Combined Hydrogen, Heat, and Power (CHHP)}

The proposed CHHP includes an electrolyzer, fuel cell, and hydrogen and heat storage. The input power of the electrolyzer is supplied by the SPL. Figure 2 shows the proposed SPL-CHHP. The model for each unit is introduced in the following.

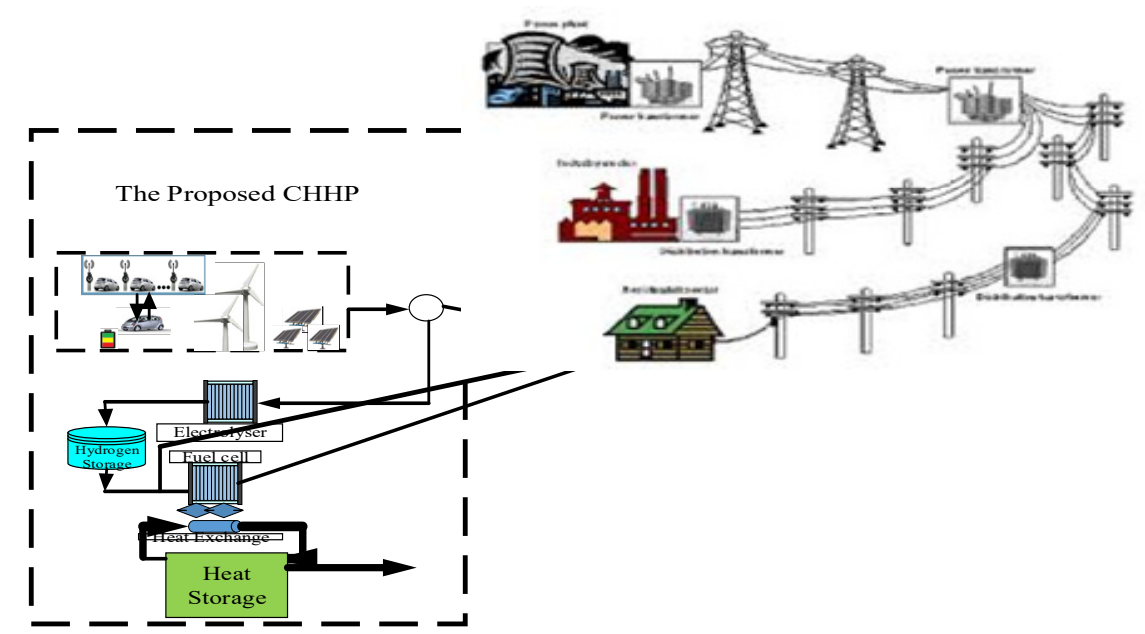

Figure 2. The proposed SPL-CHHP.

\subsubsection{Electrolyzer}

The electrolyzer decomposes water into $\mathrm{H}_{2}$ and $\mathrm{O}_{2}$. The process of decomposing water into its elementary components is carried out by passing electricity between two separated electrodes. The output power of the electrolyzer can be calculated as follows [32]:

$$
P_{t}^{\text {Out_EL }}=P_{t}^{\text {Out_SPL}} \times \eta^{E L}
$$

\subsubsection{Fuel Cell}

The fuel cell is used to generate electrical energy from the chemical energy of the oxygen and hydrogen from the electrolyzer. The output power of the fuel cell can be calculated as follows [33]:

$$
H S S_{t}=H S S_{t-1}+\eta^{P H} \times P_{t}^{P H}-\frac{P_{t}^{H P}}{\eta^{H P}}
$$


The thermal flow in the heat storage at time $t$ is formulated as follows [34]:

$$
\mathrm{Heat}_{t}^{H S}=\eta^{\mathrm{HS}} \times \mathrm{Heat}_{t-1}^{\mathrm{HS}}+\mathrm{Heat}_{t-1}^{\mathrm{HS}-\mathrm{in}}-\mathrm{Heat}_{t-1}^{\mathrm{HS}-\mathrm{out}}
$$

The upper and lower constraints of the heat storage units are defined as follows:

$$
\begin{aligned}
& \text { Heat }_{m, d, h, s}^{H S} \leq S i z e^{H S} \\
& \text { Heat } t_{m, d, h, s}^{H S-i n} \leq A_{m, d, h, s}^{H S-i n} \times \xi_{m, d, h, s}^{H S-i n} \times \overline{\text { Heat }}{ }^{H S-i n} \\
& \text { Heat }{ }_{m, d, h, s}^{H S-o u t} \leq A_{m, d, h, s}^{H S-o u t} \times \xi_{m, d, h, s}^{H S-o u t} \times \overline{\text { Heat }^{H S-o u t}} \\
& \xi_{m, d, h, s}^{H S-o u t}+\xi_{m, d, h, s}^{H S-i n} \leq 1
\end{aligned}
$$

\subsection{LSTM Model}

The long short-time memory model is used with time series data to model wind velocity and solar irradiation. To this end, among all of the received data, 70 percent of data were separated and used as training data, and the rest were used as test data to evaluate the model. The LSTM includes three layers: input, output, and hidden layers. The hidden layer is formed as a memory cell. Figure 3 illustrates the basic unit of the memory cell. Input, forget, and output are the three gates of each cell. Equation (39) shows the input, hidden, and output layers of the LSTM [35].

$$
\begin{gathered}
i_{t}=g\left(W_{x i} x_{t}+W_{h i} s_{t-1}+b_{i}\right) \\
f_{t}=g\left(W_{x f} x_{t}+W_{h f} s_{t-1}+b_{f}\right) \\
o_{t}=g\left(W_{x o} x_{t}+W_{h o} s_{t-1}+b_{o}\right)
\end{gathered}
$$

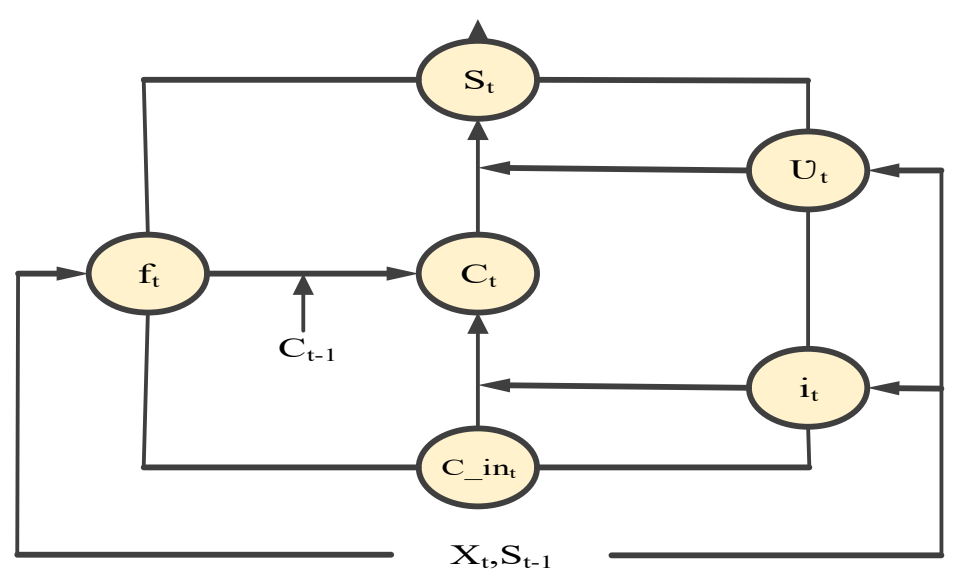

Figure 3. The basic unit memory cell.

To analyze the sensitivity and accuracy of the LSTM, the mean square error (MSE) was employed, calculated as follows:

$$
M S E=\frac{1}{k} \sum_{i=1}^{k}\left(y_{i}-\overline{y_{i}}\right)^{2}
$$

The network structure of the LSTM is shown in Figure 4. 


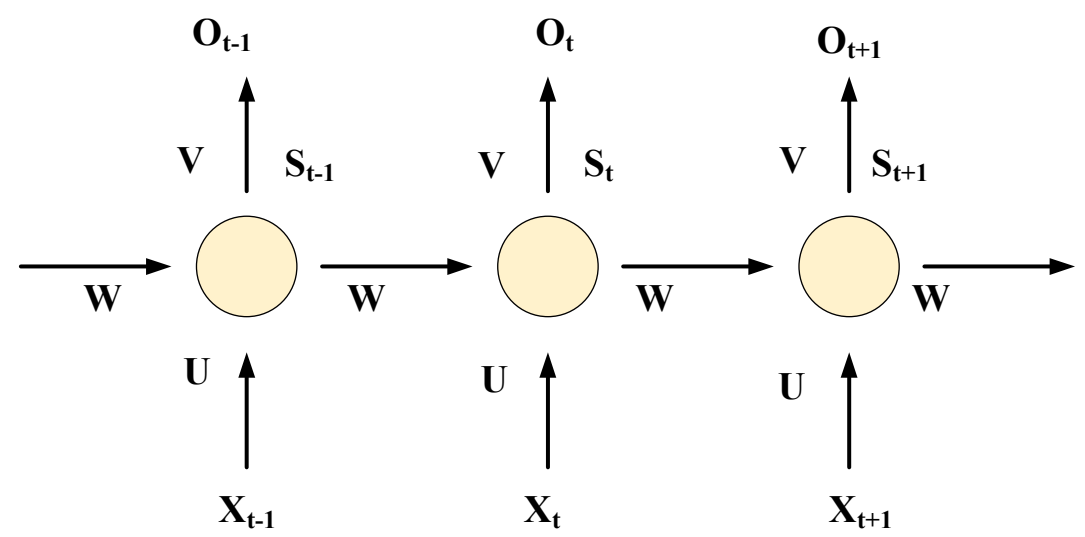

Figure 4. The basic unit memory cell.

\subsection{Demand Response}

An efficient method of consumption-side management is to establish load response programs. These programs are divided into two general types: time-based and incentiveoriented. In this research, the TOU method, which is a time-based program, was utilized. This method offers a three-tariff price based on three categories: peak, medium, and low. By implementing load response programs, the distribution network operator can shift the load from the peak and costly hours to low and cheap hours. It should be noted that subscribers' ability in the load shift is confined to a maximum value [36]. The current work could be extended by considering thermostatically controlled loads [37].

\section{Problem-Solving Algorithm}

The genetic algorithm (GA) is a search technique in computer science to find approximate solutions to optimization and search problems. It is a particular type of evolutionary algorithm that models biological processes such as inheritance and mutation [38]. This algorithm is one of the most effective search methods to determine the optimal point due to its parallel search of the answer space. The chromosomes used in the genetic algorithm to solve our objective functions are shown in Figure 5. These chromosomes are composed of three parts: the first part determines the location and size of DGs, the second part determines the power factor of DGs, and the third part determines the location of SMs.

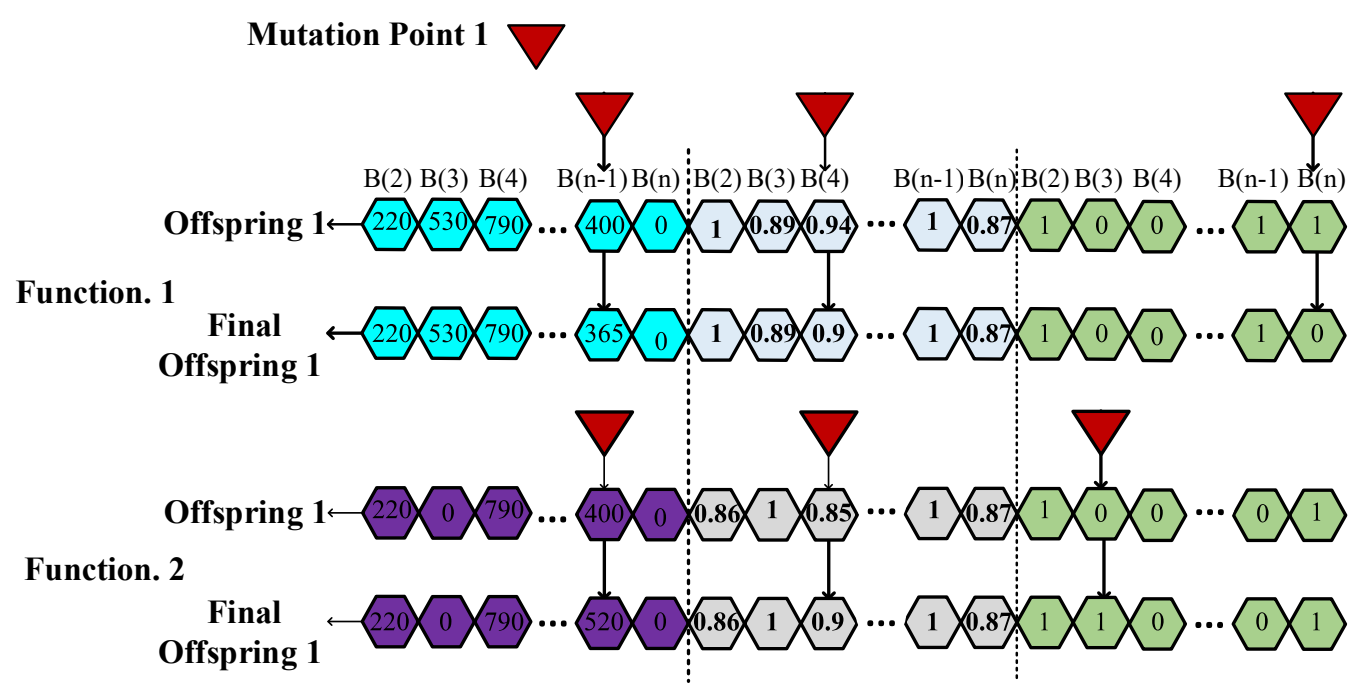

Figure 5. Chromosomes used in the GA algorithm.

Figure 6 illustrates the proposed chromosomes for the first and second objective functions separately. In each of the above functions, two other operations must be performed 
in the structure of chromosomes: the intersection operation and the mutation operation. We select two of the parents (chromosomes) and perform the intersection and mutation operations. Finally, after the mutation operation, two children are born, one of which is shown in the figure above. In each iteration, some children are generated, and after ordering the children and parents in terms of their competence in optimizing our objective function, the competent individuals enter the next iteration. After a certain number of iterations, the optimal answer is achieved, and the best chromosome is extracted as the final answer. In the end, the optimal positioning and sizing are obtained. Figure 6 shows the proposed flowchart to solve the planning problem and choose the best plan among all of the solutions.

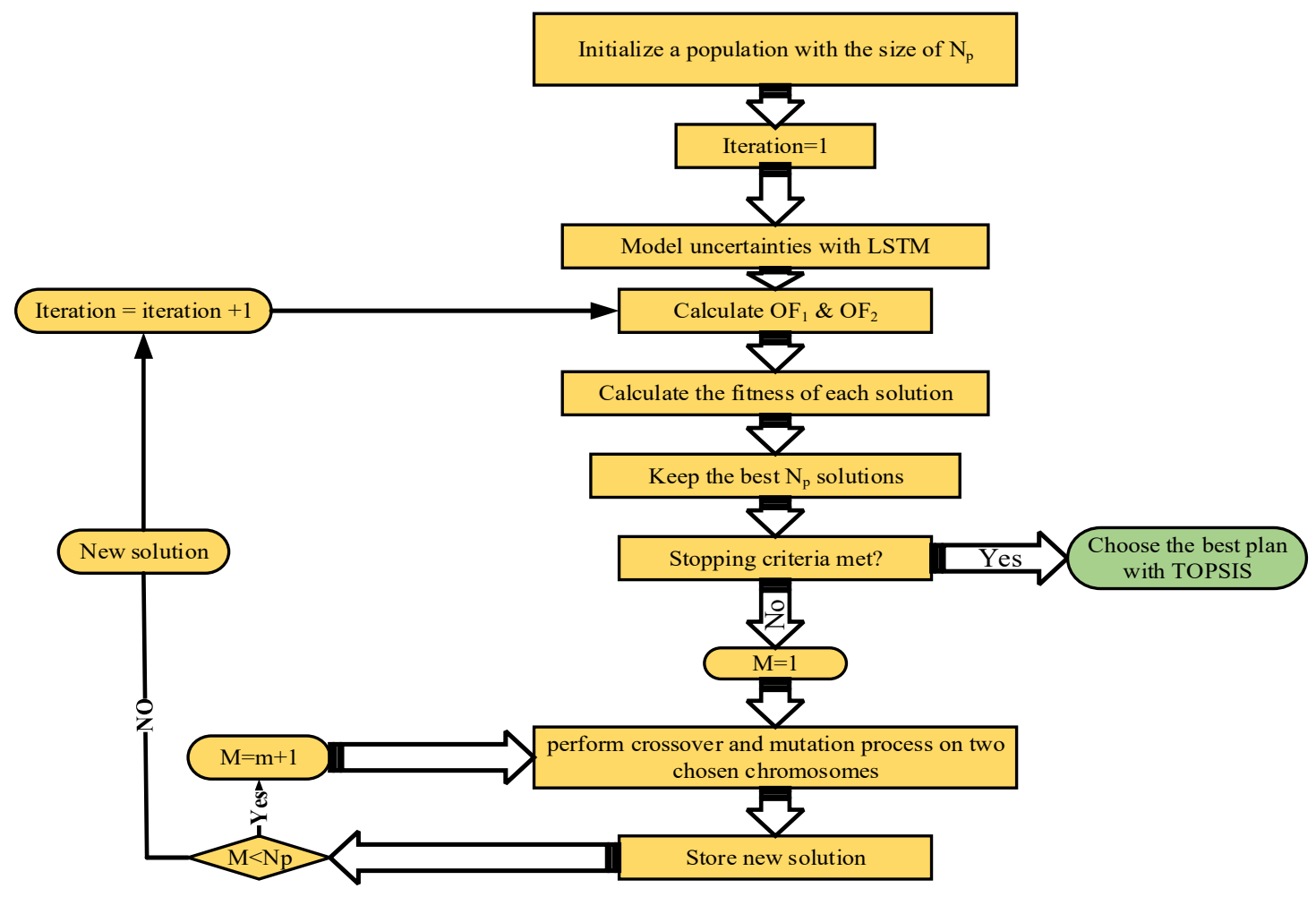

Figure 6. The proposed flowchart to solve the multiobjective function.

\section{Results}

\subsection{Input Data}

All of the required parameters to model WT, PV, HSS, HS, CHHP, and EVs are given in Tables 1 and 2. The smart charge/discharge pattern of the EVs according to the daily load curve is depicted in Figure 7.

Table 1. PV, PL, and CHHP parameters.

\begin{tabular}{|c|c|c|c|c|c|c|c|c|c|c|c|c|c|c|}
\hline Unit & & HP & & & PV & & & & PL & & & Othe & Data & \\
\hline Parameter & $\eta^{\text {Electrolyser }}$ & $\eta^{H E}$ & $\omega$ & $\eta^{P V}$ & S & $T_{a}$ & $\eta^{G 2 V}$ & $\eta^{V 2 G}$ & $S O C_{\min }$ & $S O C_{\max }$ & If & Ir & (year) $\tau$ & $\alpha$ \\
\hline Value & 0.7 & 0.85 & 0.80 & $12.5 \%$ & 800 & 25 & 0.90 & 0.81 & 0 & $8-22 \%$ & $10 \%$ & $10 \%$ & 10 & $3 \%$ \\
\hline
\end{tabular}

Table 2. TOU, WT, and fuel cell parameters.

\begin{tabular}{cccccccc}
\hline & TOU Program & \multicolumn{2}{c}{ Fuel Cell } & & WT & \\
\hline Peak & Normal & Low & & & \\
\hline $20-23$ & $7: 00-19: 59$ & $0: 00-6: 59$ & $\eta^{\text {Fuel cell }}$ & $V_{\text {Cut-in }}$ & $V_{\text {Cut-Out }}$ & $V_{\text {rated }}$ & $P_{r}$ \\
\hline $0.52(\$ / \mathrm{kWh})$ & $0.40(\$ / \mathrm{kWh})$ & $0.25(\$ / \mathrm{kWh})$ & 0.80 & 5 & 15 & 12 & 11 \\
\hline
\end{tabular}




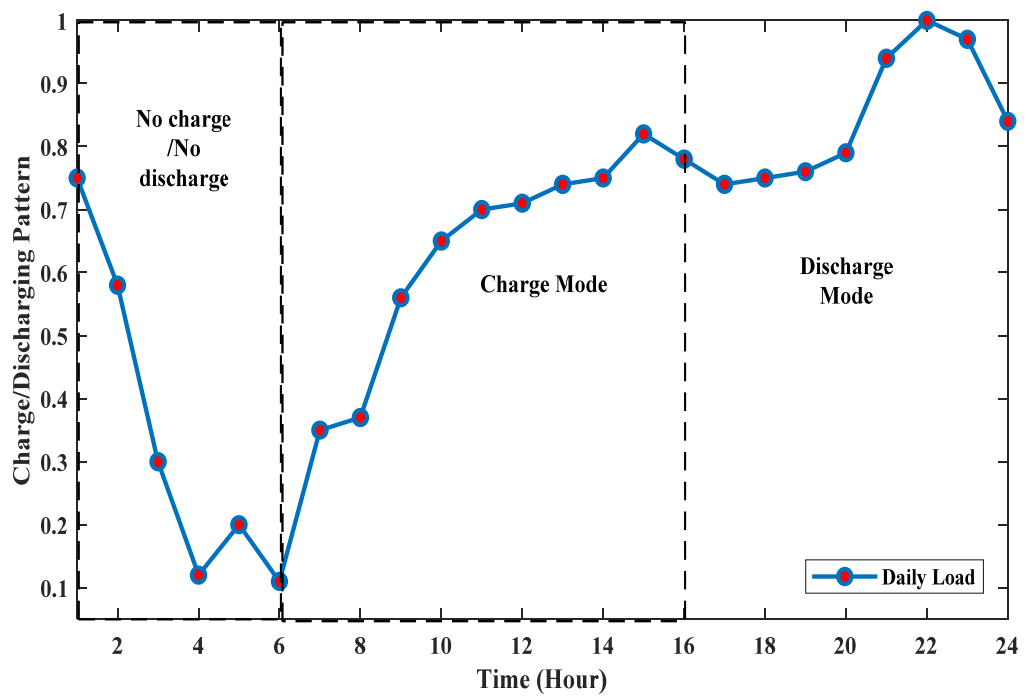

Figure 7. Charge/discharge pattern.

\subsection{Numerical Results}

To solve each of the objective functions, we examined common scenarios for each of the functions. Figure 8 shows the proposed study system. It was concluded that different scenarios could be used to optimize the location and size of distributed generation resources in different conditions:

\section{Distribution Network Operator}



Figure 8. The proposed study system.

- Scenario 1: Base state;

- Scenario 2: Optimal location of one SPL-CHHP and three SMs; 
- Scenario 3: Optimal location of two SPL-CHHP and three SMs;

- Scenario 4: Optimal location of three SPL-CHHP and three SMs.

Figures 9-11 show the efficiency of LSTM in electricity, hydrogen, and heat demand prediction.

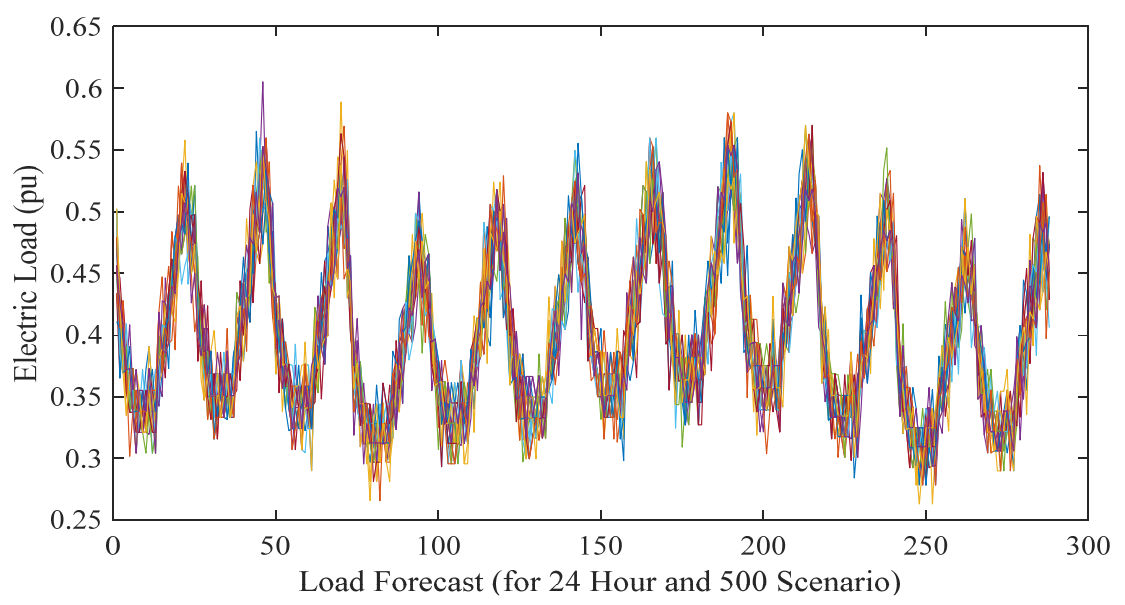

Figure 9. Electricity demand prediction using LSTM.

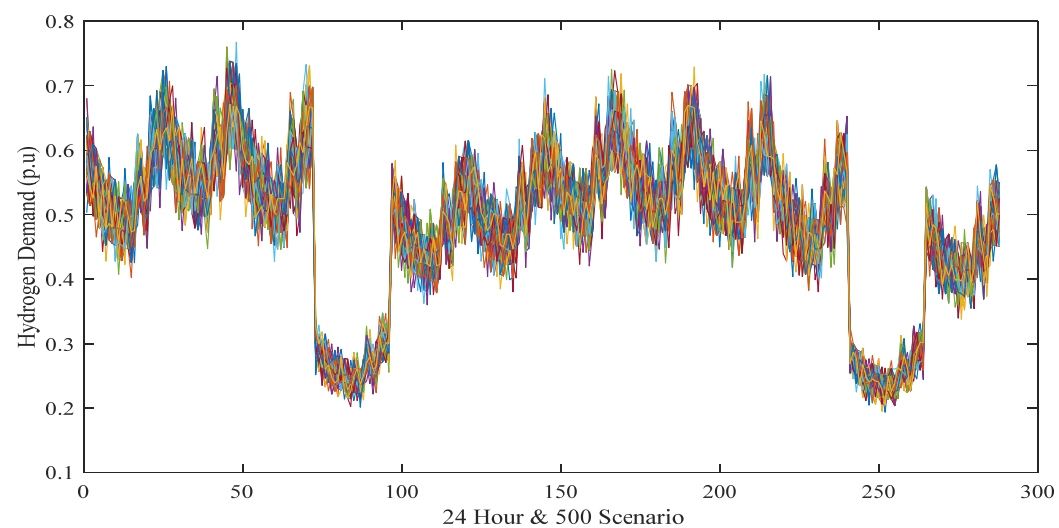

Figure 10. Hydrogen demand prediction using LSTM.

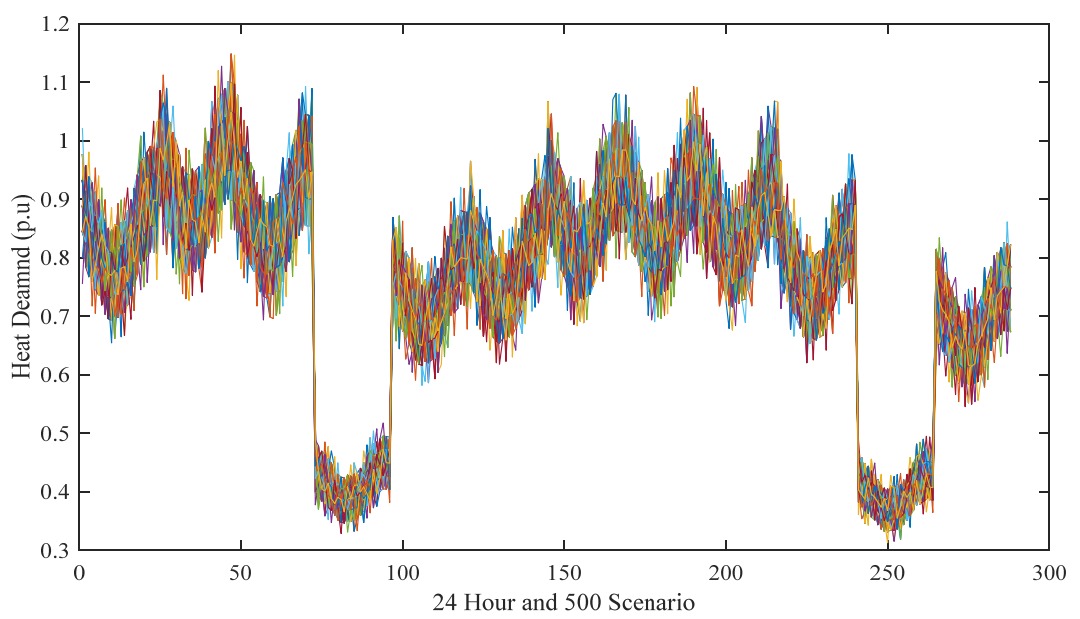

Figure 11. Heat demand prediction using LSTM.

Figures 12 and 13 show the sun irradiation and wind velocity, which were predicted via LSTM. The obtained forecasted data with minimum MSE were used as input data in the optimization algorithm. 


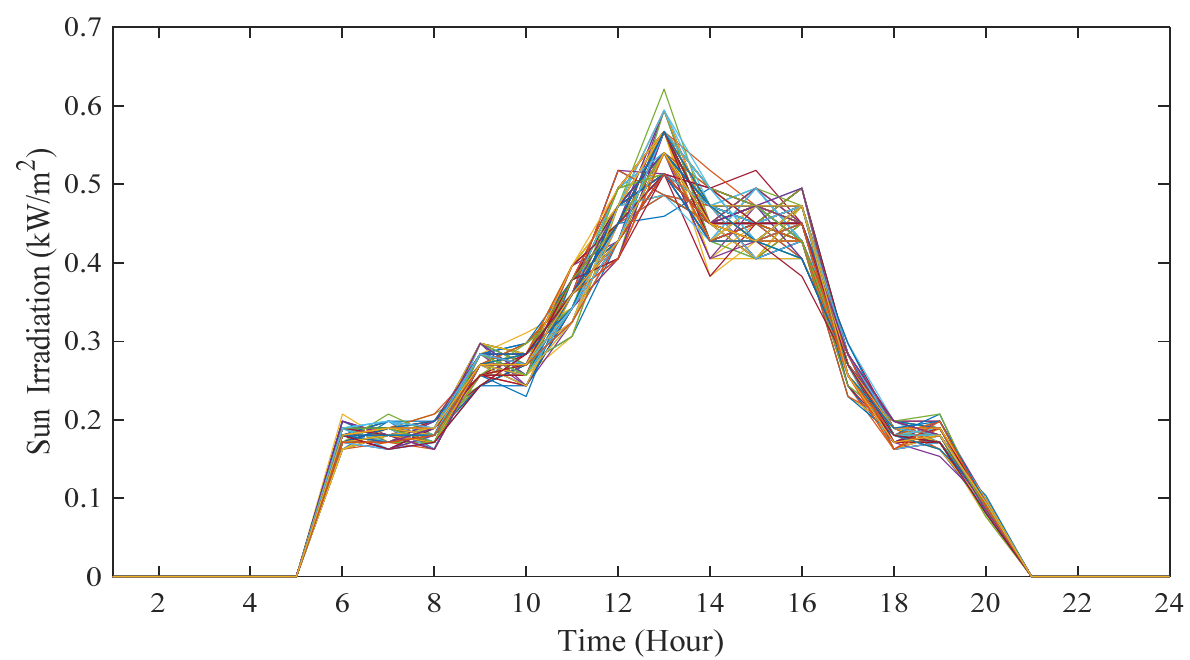

Figure 12. Sun irradiation prediction using LSTM.

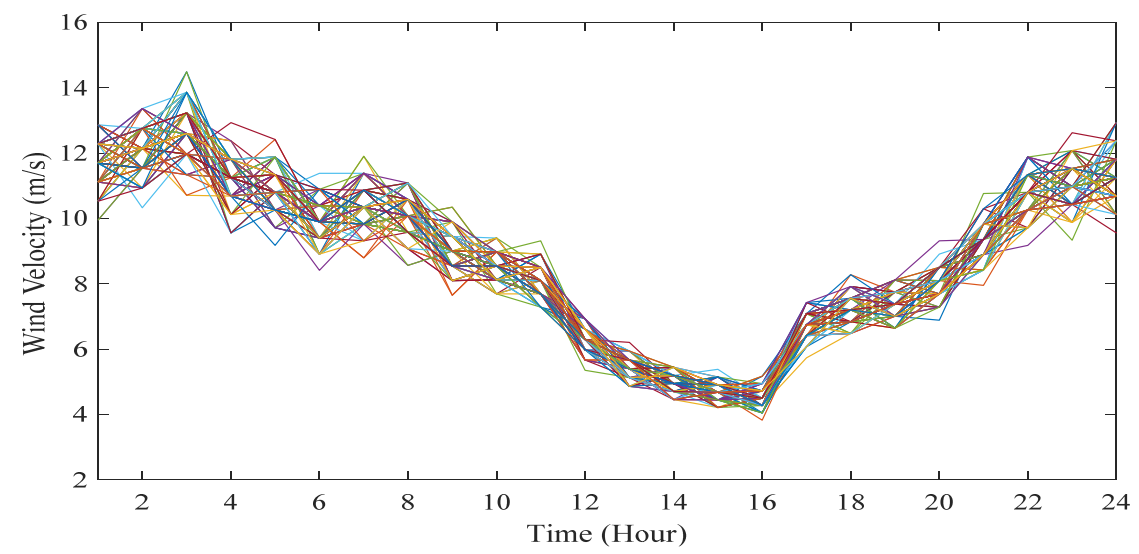

Figure 13. Wind velocity prediction using LSTM.

The converged power of CHHP in the different scenarios is illustrated in Figure 14. The base state means the state without the presence of CHHP and SM in the distribution system network. At first, simulations were carried out in the four mentioned scenarios and for two modes (with and without a DR program). The results are given in Table 3. Figures 15 and 16 show the voltage profile and power loss, respectively, in the different scenarios.

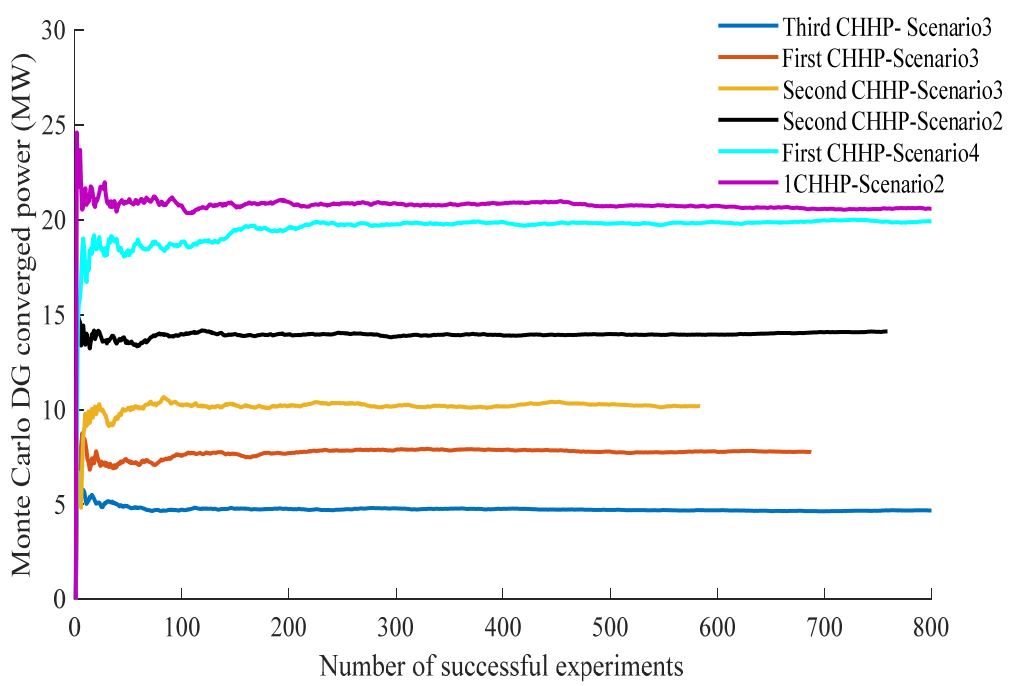

Figure 14. Converged power of CHHP. 
Table 3. Results in minimize total cost.

\begin{tabular}{|c|c|c|c|c|c|c|}
\hline Scenario & Case & $\begin{array}{c}\text { Minimum } \\
\text { Voltage (p.u.) }\end{array}$ & $\begin{array}{l}\text { Power Loss } \\
\text { Reduction }\end{array}$ & $\begin{array}{c}\text { Total Cost } \\
\left({ }^{*} 106\right)\end{array}$ & $\begin{array}{c}\text { Optimal Site } \\
\text { and Size of DGs }\end{array}$ & Optimal pf \\
\hline Scenario 1 & Base Mode & $\begin{array}{c}0.9038 \\
\mathrm{~B}(18)\end{array}$ & - & - & - & - \\
\hline \multirow{2}{*}{ Scenario 2} & Case 1 & $\begin{array}{c}0.9276 \\
\mathrm{~B}(33)\end{array}$ & 44.07 & 1.052 & 1.875(B8) & 1 \\
\hline & Case 2 & $\begin{array}{c}0.9481 \\
\mathrm{~B}(33)\end{array}$ & 60.6 & 1.048 & $1.889(\mathrm{~B} 8)$ & 0.85(B8) \\
\hline \multirow{2}{*}{ Scenario 3} & Case 1 & $\begin{array}{c}0.9586 \\
\mathrm{~B}(31)\end{array}$ & 58.68 & 1.030 & $\begin{array}{l}0.905 \text { (B13) } \\
1.012 \text { (B30) }\end{array}$ & $\begin{array}{l}1.00 \text { (B13) } \\
1.00 \text { (B30) }\end{array}$ \\
\hline & Case 2 & $\begin{array}{l}0.9724 \\
\mathrm{~B}(25)\end{array}$ & 80.6 & 1.012 & $\begin{array}{l}0.808 \text { (B16) } \\
1.089(\mathrm{~B} 30)\end{array}$ & $\begin{array}{l}0.84(\mathrm{~B} 16) \\
(\mathrm{B} 30) 0.91\end{array}$ \\
\hline \multirow{3}{*}{ Scenario 4} & Case 1 & $\begin{array}{l}0.9502 \\
\mathrm{~B}(31)\end{array}$ & 61.77 & 1.001 & (B14)0.799 & $\begin{array}{l}1.00(\mathrm{~B} 14) \\
1.00(\mathrm{~B} 25) \\
1.00(\mathrm{~B} 31)\end{array}$ \\
\hline & & 0.9475 & & & $0.91(\mathrm{~B} 14)$ & 0.579 (B14) \\
\hline & Case 2 & $\mathrm{~B}(25)$ & 86.33 & 0.985 & $\begin{array}{c}0.9(\mathrm{~B} 25) \\
0.85(\mathrm{~B} 30)\end{array}$ & $\begin{array}{l}0.847(\mathrm{~B} 25) \\
0.378(\mathrm{~B} 30)\end{array}$ \\
\hline
\end{tabular}

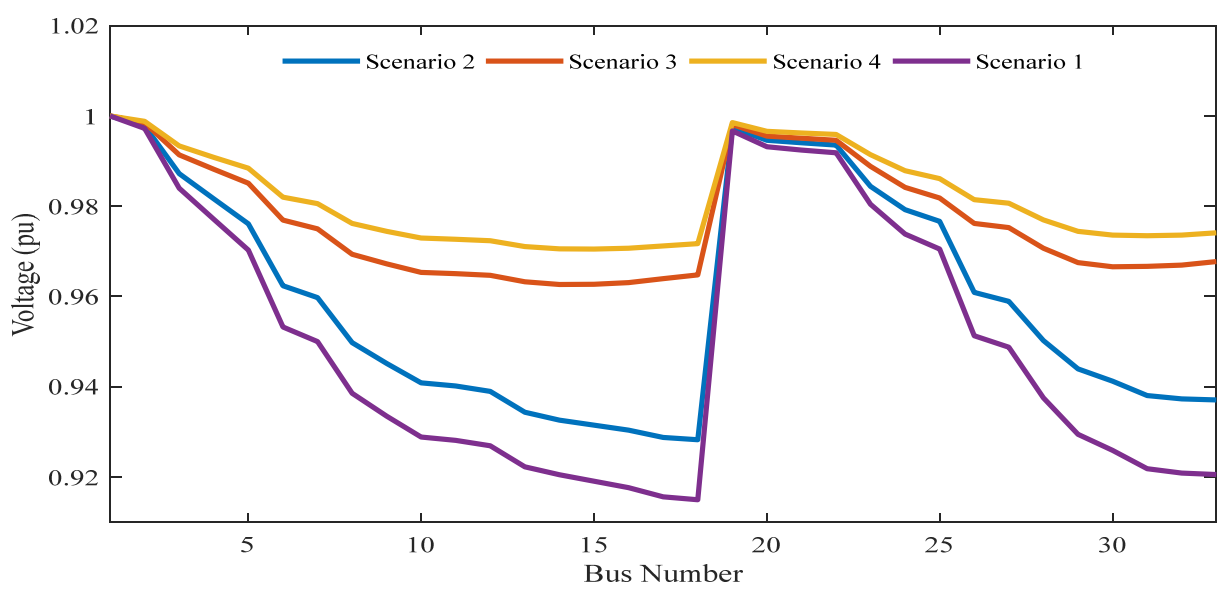

Figure 15. Voltage profile.

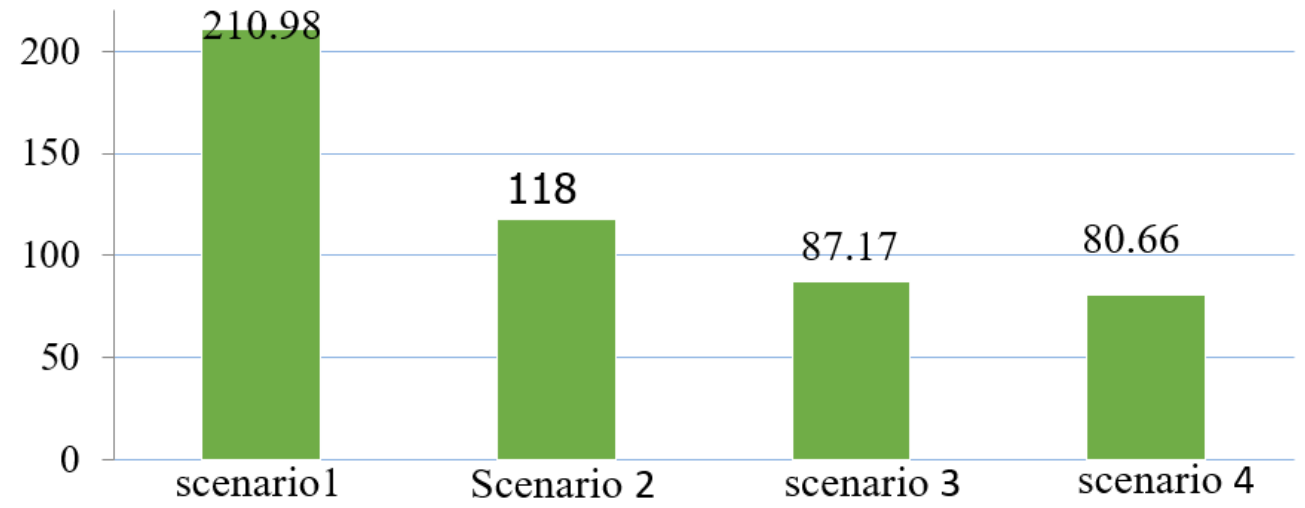

Figure 16. Power loss in the different scenarios.

In the secondary simulations, for each of Scenarios 2, 3, and 4, three modes were proposed.

- $\quad$ Mode 1: location of the CHHP in single power factor mode, without locating the SMs;

- Mode 2: location of the CHHP in the adaptive power factor mode, without the presence of SMs; 
- $\quad$ Mode 3: simultaneous location of CHHP in adaptive power factor mode and SMs.

Table 4 illustrates the results for the objective function of the voltage profile improvement. As can be seen, with increasing number of DGs and penetration of load response programs in the distribution networks, the voltage range in different buses was boosted and had a positive effect on the distribution system losses. Nonetheless, as we expected, the loss reduction in the first objective function in Scenario 4, Mode 3 was greater than that in the second objective function in the same mode. The reason for this is that the objective functions are different.

Table 4. Results in improved voltage profile function.

\begin{tabular}{|c|c|c|c|c|c|}
\hline Scenario & Mode & $\begin{array}{c}\text { Total Cost } \\
\left({ }^{* 106 \$)}\right.\end{array}$ & $\begin{array}{c}\text { Minimum } \\
\text { Voltage }\end{array}$ & $\begin{array}{c}\text { Site \& Size } \\
\text { of DG }\end{array}$ & Site of SM \\
\hline 1 & Base & 0.992 & $\begin{array}{c}0.9038 \\
\text { (B18) }\end{array}$ & - & - \\
\hline \multirow{4}{*}{2} & 1 & 1.628 & $\begin{array}{c}0.9389 \\
\mathrm{~B}(33)\end{array}$ & 1.75.0(B12) & - \\
\hline & 2 & 1.702 & $\begin{array}{l}0.9537 \\
\mathrm{~B}(33)\end{array}$ & $1.856(\mathrm{~B} 8)$ & - \\
\hline & 3 & 0.9205(B33) & $\begin{array}{c}0.9548 \\
\mathrm{~B}(33)\end{array}$ & $1.890(\mathrm{~B} 8)$ & $\begin{array}{c}\text { B6, B25, B30, } \\
\text { B31, B32 }\end{array}$ \\
\hline & 1 & 0.9115(B31) & $\begin{array}{c}0.9618 \\
\mathrm{~B}(31)\end{array}$ & $\begin{array}{l}1.352(\mathrm{~B} 14) \\
0.623(\mathrm{~B} 33)\end{array}$ & - \\
\hline \multirow[t]{3}{*}{3} & 2 & $0.9826(\mathrm{~B} 25)$ & $\begin{array}{c}0.9689 \\
\mathrm{~B}(25)\end{array}$ & $\begin{array}{l}0.988(\mathrm{~B} 17) \\
1.011(\mathrm{~B} 33)\end{array}$ & - \\
\hline & 3 & $0.9825(\mathrm{~B} 33)$ & $\begin{array}{c}0.9745 \\
\mathrm{~B}(33) \\
0.9678\end{array}$ & $\begin{array}{l}0.953(\mathrm{~B} 14) \\
1.042(\mathrm{~B} 32) \\
0.959(\mathrm{~B} 13)\end{array}$ & B7, B14, B18, B20, B32 \\
\hline & 1 & 0.9578 (B31) & $\mathrm{B}(31)$ & $\begin{array}{l}0.507(\mathrm{~B} 16) \\
0.534(\mathrm{~B} 33)\end{array}$ & - \\
\hline \multirow[t]{2}{*}{4} & 2 & $0.9512(\mathrm{~B} 25)$ & $\begin{array}{c}0.9759 \\
\mathrm{~B}(25)\end{array}$ & $\begin{array}{l}0.719(\mathrm{~B} 15) \\
0.417(\mathrm{~B} 18) \\
0.862(\mathrm{~B} 33)\end{array}$ & - \\
\hline & 3 & $0.9610(\mathrm{~B} 25)$ & $\begin{array}{c}0.9785 \\
\mathrm{~B}(25)\end{array}$ & $\begin{array}{l}0.700(\mathrm{~B} 15) \\
0.430(\mathrm{~B} 18) \\
0.870(\mathrm{~B} 28)\end{array}$ & $\mathrm{B} 8, \mathrm{~B} 29, \mathrm{~B} 30, \mathrm{~B} 31, \mathrm{~B} 32$ \\
\hline
\end{tabular}

\subsection{TOPSIS Results}

In this section, the goal is to achieve the best plan. As mentioned earlier, due to the optimization of the two objective functions and the fact that each objective function without the base state contains 9 different states, there are 18 different states total. Of these, 9 are with the first objective function and 9 are with the second objective function. For each of these 18 cases, the results for each of the objective functions were obtained. For example, with the use of the first objective function, we determined the result of optimization with a genetic algorithm for each of the functions. Figure 17 shows the TOPSIS technique.

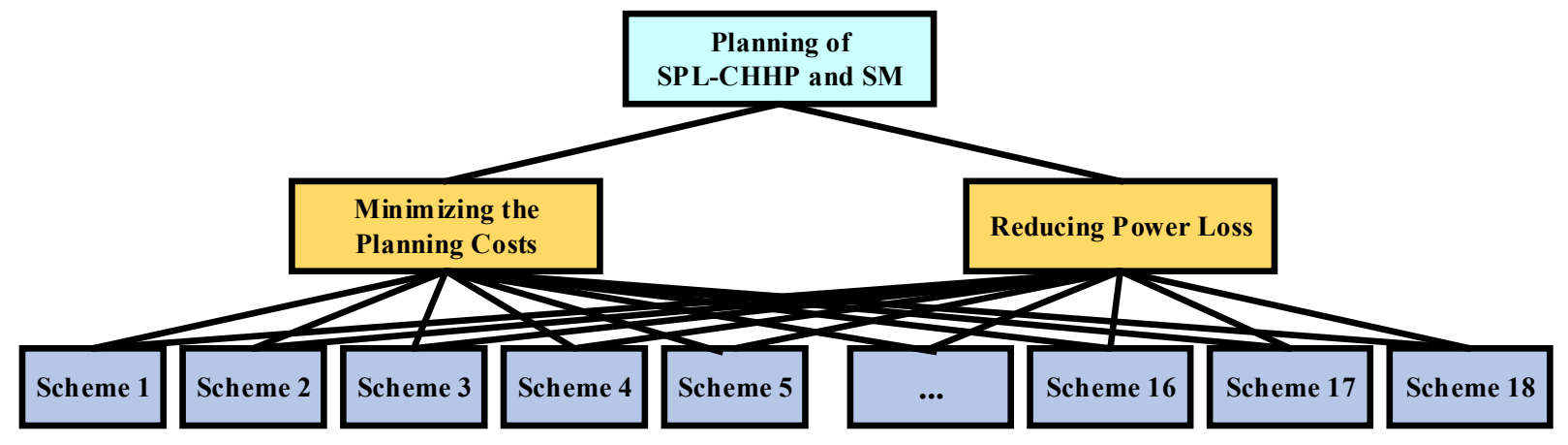

Figure 17. TOPSIS employed in the planning of SPL-CHHP. 
Thus, since there are 18 states and 2 functions, the number of alternatives will be equal to 2 , and the number of indicators will be equal to 18 .

As shown in Table 5, the most suitable plan under which both functions can be simultaneously optimized is Index Number 9. The ranking of all indexes is shown in this table. Index 9 is related to State 3 of Scenario 4, with the objective function of cost reduction. This index demonstrates a state in which both functions can be at their best at the same time.

Table 5. Given solution by employing TOPSIS.

\begin{tabular}{|c|c|c|c|c|c|c|c|}
\hline \multicolumn{2}{|c|}{ Function and Scenario } & \multicolumn{2}{|c|}{$\begin{array}{c}\text { OF1: Voltage Drop Index } \\
O F_{1}=V D I=(x, u)=\sum\left(\left|V_{i}\right|-1\right)^{2}\end{array}$} & \multicolumn{2}{|c|}{ Function and Scenario } & \multicolumn{2}{|c|}{$\begin{array}{l}\text { OF2: Minimizing Cost Function } \\
\qquad F_{2}=\min \left(I C^{C H H P}+I C^{S P L}+\right. \\
\left.\Phi_{1}+\Phi_{2}\right)\end{array}$} \\
\hline \multirow{4}{*}{$\begin{array}{c}\text { OF1 } \\
\text { Scenario2 }\end{array}$} & Mode & VDI & $\mathrm{CF}\left({ }^{*} 106 \$\right)$ & \multirow{4}{*}{$\begin{array}{c}\text { OF2 } \\
\text { Scenario2 }\end{array}$} & Mode & $\mathrm{CF}\left({ }^{*} 106 \$\right)$ & VDI \\
\hline & 1 & 0.0332 & 1.0289 & & 1 & 1.0204 & 0.0185 \\
\hline & 2 & 0.0128 & 1.0119 & & 2 & 1.0100 & 0.0110 \\
\hline & 3 & 0.0112 & 1.0101 & & 3 & 1.0098 & 0.0102 \\
\hline \multirow{3}{*}{$\begin{array}{c}\text { OF1 } \\
\text { Scenario } 3\end{array}$} & 1 & 0.0189 & 1.0126 & \multirow{3}{*}{$\begin{array}{c}\text { OF2 } \\
\text { Scenario } 3\end{array}$} & 1 & 1.0179 & 0.0152 \\
\hline & 2 & 0.0025 & 1.0012 & & 2 & 1.0096 & 0.0062 \\
\hline & 3 & 0.0021 & 1.0009 & & 3 & 1.0021 & 0.0032 \\
\hline \multirow{3}{*}{$\begin{array}{c}\text { OF1 } \\
\text { Scenario } 4\end{array}$} & 1 & 0.0248 & 1.0158 & \multirow{3}{*}{$\begin{array}{c}\text { OF2 } \\
\text { Scenario } 4\end{array}$} & 1 & 1.0178 & 0.0128 \\
\hline & 2 & 0.0058 & 1.0092 & & 2 & 1.0035 & 0.0039 \\
\hline & 3 & 0.0025 & 1.0029 & & 3 & 1.0019 & 0.0020 \\
\hline
\end{tabular}

\subsection{Comparison with Other Techniques}

The outcomes of the simultaneous solution of the two objective functions were compared with the outcomes of two other methods. In the first method, we converted the two functions into one function by applying the $\varepsilon$-constraint algorithm. Then, by solving the genetic algorithm, we acquired the solutions of the Pareto front formation. Then, utilizing the fuzzy decision-making method, the optimal answer was selected from among all the answers. In the second method, the AHP technique was utilized, which is similar to TOPSIS. The results are expressed in Table 6 below.

Table 6. Comparison of the obtained optimal Pareto fronts from different techniques.

\begin{tabular}{ccccccc}
\hline Method & $\begin{array}{c}\text { Number of Pareto } \\
\text { Optimal Solutions }\end{array}$ & $\min \left(\boldsymbol{O F}_{1}\right)$ & $\max \left(\boldsymbol{O F _ { 1 } )}\right.$ & $\min \left(\boldsymbol{O F}_{2}\right)$ & $\max \left(\boldsymbol{O F _ { 2 } )}\right.$ & $\boldsymbol{R}$ Running Time(s) \\
\hline GA + AHP & 12 & 0.2401 & 2.905 & 0.2011 & 3.899 & 28,564 \\
GA + & 16 & 0.3057 & 3.784 & 0.2089 & 3.6746 & 27,489 \\
$\varepsilon$-constraints & 10 & 0.103 & 3.985 & 0.0725 & 4.717 & 18,705 \\
GA + TOPSIS & & &
\end{tabular}

\section{Conclusions}

This work addressed the optimal siting and configuration of SPL-CHHP in a distribution network. To ensure good bilateral communication infrastructure, smart meter (SM) allocation was considered in the problem formulation. A techno-economic-based multiobjective function was proposed as the main function. Voltage drop and total investment cost reduction were defined as the technical and economic functions, respectively. The presented SPL-CHHP consists of an electrolyzer, fuel cell, heat exchange, thermal and hydrogen storage, WT, PV, and EVs. LSTM was employed to model system uncertainties. Power, thermal, and hydrogen demand, the output power of WT and PV, and the converged power of CHHP in the different scenarios were predicted via LSTM. A genetic algorithm was utilized to solve the planning problem. TOPSIS was used to choose the best plan among all of the solutions. Simulations were carried out for four scenarios. As can be seen from the results, technical criteria, such as the voltage profile and power loss reduction, were improved in the scenario with a high percentage of SPL-CHHP and SMs. 
Author Contributions: Conceptualization, H.H.; edit, review and supervision, B.M.-I.; Supervision, M.M. All authors have read and agreed to the published version of the manuscript.

Funding: The authors appreciate the support of Research Affairs Office of the University of Tabriz, Tabriz, Iran (grant number S-1610).

Conflicts of Interest: The authors confirm that this article content has no conflict of interest.

\section{Nomenclature}

Indices

\begin{tabular}{|c|c|}
\hline$i$ & CHHP index \\
\hline$j$ & SPL index \\
\hline$z$ & WT index \\
\hline$l$ & WT index \\
\hline $\mathrm{h}$ & Electrolyzer index \\
\hline$m$ & Fuel cell index \\
\hline$t$ & Time index \\
\hline $\mathrm{k}$ & Index related to branches \\
\hline \multicolumn{2}{|c|}{ Parameters } \\
\hline$O F_{1}$ & First objective function \\
\hline $\mathrm{OF}_{2}$ & Second objective function \\
\hline Ploss & Active power loss (kW) \\
\hline$V_{n, t}$ & Voltage of bus $n$ at time $t$ \\
\hline$V_{m, t}$ & Voltage of bus $\mathrm{m}$ at time $t$ \\
\hline$V_{i}$ & Voltage of bus $i$ \\
\hline$V D I$ & Voltage drop index \\
\hline$I C^{\mathrm{CHHP}}$ & Total installation cost of CHHP (\$) \\
\hline$I C^{S P L}$ & Total installation cost of the smart parking lot (\$) \\
\hline$\Phi_{1}$ & Total operational cost $(S)$ \\
\hline$\Phi_{2}$ & Total emissions cost $(\mathrm{S})$ \\
\hline$\rho_{t}$ & Price of purchased electricity $(\$ / \mathrm{kWh})$ \\
\hline$P_{t}^{U G}$ & Amount of purchased power from the main grid $(\mathrm{kW})$ \\
\hline$P_{t}^{S P L}$ & Output power of the SPL $(\mathrm{kW})$ \\
\hline$P_{t}^{C H H P}$ & Output power of CHHP (kW) \\
\hline$P_{t}^{W T}$ & Amount of power produced by WT $(\mathrm{kW})$ \\
\hline$P_{t}^{P V}$ & Amount of power produced by PV $(\mathrm{kW})$ \\
\hline$D_{t}^{C H H P}$ & Emissions per $\mathrm{kWh}$ from $\mathrm{CHHP}(\mathrm{kg} / \mathrm{kW})$ \\
\hline$D_{t}^{S P L}$ & Emissions per $\mathrm{kWh}$ from SPL $(\mathrm{kg} / \mathrm{kW})$ \\
\hline$D_{t}^{U G G}$ & Emissions per $\mathrm{kWh}$ from UG $(\mathrm{kg} / \mathrm{kW})$ \\
\hline$\alpha^{t^{t}}$ & Load growth at time $t$ \\
\hline$S_{\text {ibase }}$ & Base complex power (kVA) \\
\hline$Q_{\text {ibase }}$ & Base reactive power (kVar) \\
\hline$\delta_{t, h}$ & Variance of price prediction \\
\hline$\rho_{t, h}$ & Price of purchased energy from the main grid $(\$ / \mathrm{kWh})$ \\
\hline$\delta_{S O C}^{2}$ & State of charge variance \\
\hline$\delta_{\text {arv }}^{2}$ & Variance in the EV's arrival at the SPL \\
\hline$\delta_{d e p}^{2}$ & Variance in the EV's departure from the SPL \\
\hline$H S S_{t}$ & Hydrogen exchange at time $t$ \\
\hline Size $e^{H S}$ & Capacity of heat storage \\
\hline$\delta^{H S-O u t}$ & Binary value to show outflow heat energy \\
\hline$W_{x i}$ & Weight of $x_{i}$ \\
\hline$W_{x o}$ & Weight of $x_{0}$ \\
\hline$X_{t}$ & Input variable at time $t$ \\
\hline$W_{h o}$ & Weight of ho \\
\hline$S_{t-1}$ & State at time $t-1$ \\
\hline$S O C_{t}^{E V}$ & EV's state of charge at time $t$ \\
\hline$\eta_{\text {disch }}^{E V}$ & EV's discharge efficiency \\
\hline$\eta_{c h}^{E V}$ & EV's charge efficiency \\
\hline$\mu_{t, h}$ & Mean value of price prediction \\
\hline
\end{tabular}




$\begin{array}{ll}S O C_{k}^{\text {initial }} & \text { Initial value of SOC } \\ \mu_{S O C} & \text { Mean value of SOC prediction } \\ S_{S O C_{k}^{\text {initialmax }}} & \text { Maximum value of initial SOC } \\ S_{k} C_{k}^{\text {initialmin }} & \text { Minimum value of initial SOC } \\ t_{k}^{\text {dep }} & \text { Time of discharged power } \\ t_{k}^{\text {arv }} & \text { Time of charging power } \\ X_{t}^{E C-C h} & \text { Binary variable of charging mode } \\ X_{t}^{E C-d i s c h} & \text { Binary variable of discharging mode } \\ P_{t}^{E V-C h} & \text { Charging power of EV }(\mathrm{kW}) \\ P_{t}^{E V-d i s c h} & \text { Discharging power of EV }(\mathrm{kW}) \\ V_{C u t \_o u t} & \text { Cut-out velocity of the WT (m/s) } \\ V_{\text {rated }} & \text { Rated velocity of the WT (m/s) } \\ \eta^{P V} & \text { Efficiency of converting irradiation to electricity in the PV } \\ A & \text { Surface of the PV cell } \\ T_{a} & \text { Ambient temperature } \\ I r & \text { Absorbed irradiation } \\ f(\text { Ir }) & \text { Probabilistic distribution of the Ir } \\ \alpha, \beta & \text { Parameters of the sun irradiation prediction PDF } \\ \eta^{E L} & \text { Efficiency of the electrolyzer } \\ \eta^{f u e l c ~ c e l l ~} & \text { Efficiency of the fuel cell } \\ \eta^{\text {Heat }} & \text { Heat storage efficiency } \\ \chi & \text { Efficiency of transferring thermal energy }\end{array}$

\section{References}

1. Zhang, X.; Shahidehpour, M.; AlAbdulwahab, A.; Abusorrah, A. Optimal expansion planning of energy hub with multiple energy infrastructures. IEEE Trans. Smart Grid 2015, 6, 2302-2311. [CrossRef]

2. Morvaj, B.; Evins, R.; Carmeliet, J. Optimizing urban energy systems: Simultaneous system sizing, operation and district heating network layout. Energy 2016, 116, 619-636. [CrossRef]

3. Coelho, B.; Andrade-Campos, A. Energy recovery in water networks: Numerical decision support tool for optimal site and selection of micro turbines. J. Water Resour. Plan. Manag. 2018, 144, 04018004. [CrossRef]

4. Delfino, F.; Ferro, G.; Minciardi, R.; Robba, M.; Rossi, M.; Rossi, M. Identification and optimal control of an electrical storage system for microgrids with renewables. Sustain. Energy Grids Netw. 2019, 17, 100183. [CrossRef]

5. Rostami, R.; Hosseinnia, H. Impacts of Contributing Distribution Network Operator (DNO) and Distributed Generation Unit Operator (DGO) in Benefit Maximizing. In Proceedings of the 7th Iran Wind Energy Conference (IWEC2021), Shahrood, Iran, 17-18 May 2021; pp. 1-4.

6. Hosseinnia, H.; Nazarpour, D.; Talavat, V. Benefit maximization of demand side management operator (DSMO) and private investor in a distribution network. Sustain. Cities Soc. 2018, 40, 625-637. [CrossRef]

7. Thirugnanam, K.; Kerk, S.K.; Yuen, C.; Liu, N.; Zhang, M. Energy management for renewable microgrid in reducing diesel generators usage with multiple types of battery. IEEE Trans. Ind. Electron. 2018, 65, 6772-6786. [CrossRef]

8. Gbadamosi, S.; Nwulu, N.I. Optimal power dispatch and reliability analysis of hybrid CHP-PV-wind systems in farming applications. Sustainability 2020, 12, 8199. [CrossRef]

9. Misconel, S.; Zöphel, C.; Möst, D. Assessing the value of demand response in a decarbonized energy system-A large-scale model application. Appl. Energy 2021, 299, 117326. [CrossRef]

10. Duman, A.C.; Erden, H.S.; Gönül, Ö.; Güler, Ö. A home energy management system with an integrated smart thermostat for demand response in smart grids. Sustain. Cities Soc. 2021, 65, 102639. [CrossRef]

11. Abdelaziz, M. GPU-OpenCL accelerated probabilistic power flow analysis using Monte-Carlo simulation. Electr. Power Syst. Res. 2017, 147, 70-72. [CrossRef]

12. Qin, B.; Fang, C.; Ma, K.; Li, J. Probabilistic energy flow calculation through the nataf transformation and point estimation. Appl. Sci. 2019, 9, 3291. [CrossRef]

13. Said, S.M.; Ali, A.; Hartmann, B. Tie-line power flow control method for grid-connected microgrids with SMES based on optimization and fuzzy logic. J. Mod. Power Syst. Clean Energy 2020, 8, 941-950. [CrossRef]

14. Wei, X.; Xie, Z.; Cheng, R.; Zhang, D.; Li, Q. An Intelligent Learning and Ensembling Framework for Predicting Option Prices. Emerg. Mark. Financ. Trade 2020, 12, 1-24. [CrossRef]

15. Shivaie, M.; Kiani-Moghaddam, M.; Weinsier, P.D. Bilateral bidding strategy in joint day-ahead energy and reserve electricity markets considering techno-economic-environmental measures. Energy Environ. 2021, 6, 0958305X211014875.

16. Giap, V.-T.; Lee, Y.D.; Kim, Y.S.; Ahn, K.Y. A novel electrical energy storage system based on a reversible solid oxide fuel cell coupled with metal hydrides and waste steam. Appl. Energy 2020, 262, 114522. [CrossRef] 
17. Singh, S.; Chauhan, P.; Singh, N. Capacity optimization of grid connected solar/fuel cell energy system using hybrid ABC-PSO algorithm. Int. J. Hydrog. Energy 2020, 45, 10070-10088. [CrossRef]

18. Sorlei, I.-S.; Bizon, N.; Thounthong, P.; Varlam, M.; Carcadea, E.; Culcer, M.; Iliescu, M.; Raceanu, M. Fuel cell electric vehicles-A brief review of current topologies and energy management strategies. Energy 2021, 14, 252.

19. Mohseni, S.; Brent, A.C.; Burmester, D.; Browne, W.N. Lévy-flight moth-flame optimisation algorithm-based micro-grid equipment sizing: An integrated investment and operational planning approach. Energy AI 2021, 3, 100047. [CrossRef]

20. Suresh, M.; Meenakumari, R. Optimum utilization of grid connected hybrid renewable energy sources using hybrid algorithm. Trans. Inst. Meas. Control 2021, 43, 21-33. [CrossRef]

21. Bahmani, R.; Karimi, H.; Jadid, S. Stochastic electricity market model in networked microgrids considering demand response programs and renewable energy sources. Int. J. Electr. Power Energy Syst. 2020, 117, 105606. [CrossRef]

22. Arévalo, P.; Tostado-Véliz, M.; Jurado, F. A novel methodology for comprehensive planning of battery storage systems. J. Energy Storage 2021, 37, 102456. [CrossRef]

23. Tostado-Véliz, M.; Icaza-Alvarez, D.; Jurado, F. A novel methodology for optimal sizing photovoltaic-battery systems in smart homes considering grid outages and demand response. Renew. Energy 2021, 170, 884-896. [CrossRef]

24. Khasanov, M.; Kamel, S.; Rahmann, C.; Hasanien, H.M.; Al-Durra, A. Optimal distributed generation and battery energy storage units integration in distribution systems considering power generation uncertainty. IET Gener. Transm. Distrib. 2021, 2, 1-23.

25. Ahrabi, M.; Abedi, M.; Nafisi, H.; Mirzaei, M.A.; Mohammadi-Ivatloo, B.; Marzband, M. Evaluating the effect of electric vehicle parking lots in transmission-constrained AC unit commitment under a hybrid IGDT-stochastic approach. Int. J. Electr. Power Energy Syst. 2021, 125, 106546. [CrossRef]

26. Kong, X.; Liu, D.; Wang, C.; Sun, F.; Li, S. Optimal operation strategy for interconnected microgrids in market environment considering uncertainty. Appl. Energy 2020, 275, 115336. [CrossRef]

27. Cai, S.; Xie, Y.; Wu, Q.; Xiang, Z. Robust MPC-based microgrid scheduling for resilience enhancement of distribution system. Int. J. Electr. Power Energy Syst. 2020, 121, 106068. [CrossRef]

28. Shi, Q.; Li, F.; Olama, M.; Dong, J.; Xue, Y.; Starke, M.; Winstead, C.; Kuruganti, T. Network Reconfiguration and Distributed Energy Resource Scheduling for Improved Distribution System Resilience. Int. J. Electr. Power Energy Syst. 2021, 124, 106355. [CrossRef]

29. Zhou, M.; Wu, Z.; Wang, J.; Li, G. Forming dispatchable region of electric vehicle aggregation in microgrid bidding. IEEE Trans. Ind. Inform. 2020, 17, 4755-4765. [CrossRef]

30. Ebrahimi, J.; Abedini, M.; Rezaei, M.M.; Nasri, M. Optimum design of a multi-form energy in the presence of electric vehicle charging station and renewable resources considering uncertainty. Sustain. Energy Grids Netw. 2020, 23, 100375. [CrossRef]

31. Ghotge, R.; Snow, Y.; Farahani, S.; Lukszo, Z.; Van Wijk, A. Optimized scheduling of EV charging in solar parking lots for local peak reduction under EV demand uncertainty. Energies 2020, 13, 1275. [CrossRef]

32. Langenmayr, U.; Wang, W.; Jochem, P. Unit commitment of photovoltaic-battery systems, An advanced approach considering uncertainties from load, electric vehicles, and photovoltaic. Appl. Energy 2020, 280, 115972. [CrossRef]

33. Okpokparoro, S.; Sriramula, S. Uncertainty modeling in reliability analysis of floating wind turbine support structures. Renew. Energy 2021, 165, 88-108. [CrossRef]

34. Luo, L.; Abdulkareem, S.S.; Rezvani, A.; Miveh, M.R.; Samad, S.; Aljojo, N.; Pazhoohesh, M. Optimal scheduling of a renewable based microgrid considering photovoltaic system and battery energy storage under uncertainty. J. Energy Storage 2020, 28, 101306. [CrossRef]

35. Gül, M.; Akyüz, E. Hydrogen generation from a small-scale solar photovoltaic thermal (PV/T) electrolyzer system: Numerical model and experimental verification. Energies 2020, 13, 2997. [CrossRef]

36. Van Houdt, G.; Mosquera, C.; Nápoles, G. A review on the long short-term memory model. Artif. Intell. Rev. 2020, 53, 5929-5955. [CrossRef]

37. Tostado-Véliz, M.; Bayat, M.; Ghadimi, A.A.; Jurado, F. Home energy management in off-grid dwellings: Exploiting flexibility of thermostatically controlled appliances. J. Clean. Prod. 2021, 310, 127507. [CrossRef]

38. Kirkerud, J.G.; Nagel, N.O.; Bolkesjø, T.F. The role of demand response in the future renewable northern European energy system. Energy 2021, 235, 121336. [CrossRef] 